\title{
Investigation of The Effectiveness of Teucrium Orientale L. Plant in Hemorrhoid Treatment
}

\author{
Nuray Emin'1, Kıymet Nural ${ }^{2}$, Ayşegül Güzel ${ }^{3}$
}

${ }^{1}$ Biomedical Engineering Department, Faculty of Engineering and Architecture, Kastamonu University, 37200 Kastamonu, Turkey ${ }^{2}$ Genetics and Bioengineering Department, Faculty of Engineering and Architecture, Kastamonu University, 37200 Kastamonu, Turkey ${ }^{3}$ Institu of Science, Sustainable Agriculture and Natural Plant Resources, Kastamonu University, 37200 Kastamonu, Turkey

\section{A R T I C L E I N F O}

\section{Research Article}

Received 21 November 2017

Accepted 25 December 2017

Keywords:

Teucrium orientale L.

Haemorrhoids

Plant extract

Beyköy

Herbal remedies

*Corresponding Author:

E-mail: nurayemin@gmail.com

\section{A B S T R A C T}

Hemorrhoids are swollen vascular vein pads in the upper part of the anal canal. The deformations in these tissues cause serious disturbances, and most important one is hemorrhoid, which is a symptomatic degenerative disease. Due to various etiologic factors, weakening and disintegration of connective tissue cause this disease. Many methods have been developed in the treatment of hemorrhoids from the past to the present day, and drug therapy is used as primary care. However, surgical treatment methods are applied in advanced stages in which the disease can not be treated with medication and when there is a life-threatening risk. As alternative medicine applications, herbal remedies have been used in hemorrhoid treatment for centuries. Prepared herbal mixtures or extracts are still frequently preferred by the patients today. In this context, in the research we have carried out in Beyköy village of Havza district; Teucrium orientale $L$. are used by regional people in the treatment of hemorrhoids and it was detected that the awareness of this herbal treatment is limited. In this study, the efficacy of $T$. orientale $L$. plant in hemorrhoid treatment was evaluated by conducting a questionnaire survey on the patients using plant extract. Of the approximately 500 patients using plant extracts, 89 agreed to fill out the questionnaire. Due to the results of the survey, it was found that all of the patients using the extract of $T$. orientale $L$. plant are healed partly or completely, and the benefit from the extract changed according to the patient's age and the stage of the disease. There has been no study on the use of this plant in the treatment of hemorrhoids in literature, and it is the first study to be done in this respect.

DOI: https://doi.org/10.24925/turjaf.v6i3.326-332.1705

\section{Introduction}

Hemorrhoids are normal anatomic structures found in the anal canal (Brozovich, 2007). These structures are vascular tissue pads which are quite rich the muscle layer, blood vessels, and submucosal layer (Kann and Whitlow, 2004; Acheson and Scholefield, 2003). Hemorrhoidal cushions are supported by connective tissue and provide to control of urination and easy passage of the fecal. (Cirocco, 2007; Gearhart, 2004).

Hemorrhoidal disease is a symptomatic, degenerative disease that is usually not acute, with emerges in the history references that illuminate many ancient years (Thomson et. al., 2007). Investigations have shown that weakening connective tissue supporting hemorrhoids move downwards-in hemorrhoids and cause other symptoms such as bleeding (Cirocco, 2007). It is thought that this weakening of the connective tissue supporting hemorrhoids is due to constipation, diarrhea, pregnancy, prolonged standing, prolonged sitting, eating habits, inheritance, age, inflammatory diseases, alcohol, heart failure, cirrhosis and intraabdominal tumors. All of these etiologic factors cause the hemorrhoid tissue to work in the direction of stretching and slipping, causing the anatomical structures to weaken. As a result, the hemorrhoidal tissue becomes saggy and susceptible to injury over time (Acheson and Scholefield, 2003; Cirocco, 2007; Alabaz, 2007).

In classifying hemorrhoidal disease, the dentate line functions as the histological boundary. The external hemorrhoids are located under the dentate line, and this area is also covered by the modified squamous epithelium. For this reason, it is quite rich in terms of somatic pain fibers. Internal hemorrhoids are located on the dentate line and this region is covered with mucosa (Kaidar-Person et al., 2007). Internal hemorrhoids are classified by their location in the anal canal. This classification is given below.

First-Stage hemorrhoids: It does not form prolapse, but its symptoms include discomfort and painless bleeding. 
Second-Stage hemorrhoids: The hemorrhoidal tissue sags during defecation but can return to its former position at the end of defecation. Bleeding and perianal discharge are common symptoms.

Third-Stage hemorrhoids: Hemorrhoidal tissue is sagging out of the anal canal. Bleeding, discharge and itching are common symptoms.

Forth-Stage hemorrhoids: Hemorrhoidal tissue sags from the anal canal and does not return to its original position. Bleeding, discharge, pain, fecal contamination and pruritus are among the common symptoms (Kann and Whitlow, 2004; Kaidar-Person et al., 2007; Osmanoglu and Ünalp, 2007).

The hemorrhoidal disease manifestation is due to the loss of support of the hemorrhoidal cushions, resulting in weakening of the tissues supporting the anorectal component, which is caused by accumulation of blood circulation obstruction. Rectal bleeding, pain, prolapse, oedema, thrombosis, perianal discharge and itching are among the symptoms of hemorrhoid disease (Brozovich and Read, 2007; Şen, 2007; Popowichte and Orkin, 2013; Sack, 2003).

In the treatment of hemorrhoid disease, there are different treatment modalities from herbal therapy to surgical treatment (Kann and Whitlow, 2004; Warusavitarne and Philllips, 2007; Ganz, 2013; Moult et al, 2015). Patients are generally embarrassed by the situation they are in and are afraid to go to the doctor accordingly. In this case, the patients tend to alternative treatment and they prefer the herbal treatment methods frequently (Ahad et al, 2010). Hemorrhoid treatment usually uses drugs such as anti-inflammatory, analgesic, wound healing, and many plants with similar effects appear to be used as medicines among the folk (Gürhan and Ezer, 2004).

Plants produce a number of chemical substances known as secondary metabolites and many secondary metabolites are used by humans as healing agents in the treatment of hemorrhoids (Altundag and Öztürk, 2011). Local people are preparing medicines using wild plants in simple ways to obtain these secondary metabolites. Preparation methods include raw use, boiling, mashed, molasses, and drying. Among the methods of use, oral consumption and non-oral use methods are observed. Frequently used in these preparation methods are water boiling, infusion and dried fruit pulp formation (Güneş et al, 2017; Özdemir and Alpınar, 2015).

It is known that 60 different plant families are utilized in the herbal treatment of hemorrhoids. The plants used are mainly composed of plants belonging to different families such as Asteraceae, Lamiaceae, Rosaceae and Fabaceae. In the treatment of hemorrhoids, the various parts of these plants are used, but their leaves are generally utilized (Gürhan and Ezer, 2004; Altundag and Öztürk, 2011; Güneş et al, 2017; Tetik et al., 2013; Koca et al., 2017).

In our research in Samsun province, Havza district, Beyköy village, we have obtained the information that the public in the treatment of hemorrhoid disease used a plant growing in arid and stony soil. In interviews with local residents, it was determined that the plant did not have a local name but was used for hemorrhoid treatment for about 10 years.
It has been learned that this plant has been collected together with its roots after flowering in June-July, and then dried and stored. Dried and fresh plant samples were collected for the analyses. In the research carried out in the Biology Department Herbarium of Gazi University Faculty of Science and Literature, it was detected that this plant was Teucrium orientale L. var. orientale $L$.

$T$. orientale $L$. is the subtype of the Teucrium genus of the Lamiaceae family. In some regions of Anatolia, it is called "Kirve otu", but in some regions this name uses for other sub species. It spreads in dry and arid places in Anatolia. It is a perennial herbaceous plant. Flowering time is between June and September. It is usually grown in sparse oak, pinus forests, meadows and rocky slopes. It is not an endemic species and is distributed at an elevation of 600-2150 m. Overall distribution is in Çankırı, Amasya, Ankara, Erzurum, Eskişehir, Gümüşhane, Isparta, Konya, Manisa, Muş, Niğde, Sivas, Van in Turkey, although it is Caucasia, Iran, Syria and Lebanon (Çakır et al, 2006; Url 1).

Teucrium species in Turkish folk medicine are still used today due to their different pharmacological properties such as antipyretic, antimicrobial, antiinflammatory, anti-ulcerative, antitumor and insecticide (Bağc1 et al, 2010). In the ethnopharmacological studies conducted, it is seen that 8 taxa belonging to Teucrium 4 species were used in the treatment of hemorrhoid disease among the population. Among these plants, which are used in public and encountered in ethnopharmocological researches; Teucrium chamaedrys L., T. chamaedrys L. subsp. chamaedrys, T. chamaedrys L. subsp lydium O Schwarz, T. chamaedrys L. subsp tauricolum Rech.f. T. flavum L. subsp hellenicum Rech.f., T. parviflorum Schreb, T. polium L. (Sevgi and Kizilarslan, 2013; Özdemir and Alpınar, 2015).

T. chamaedrys L. flowering plant has 5 taxa known to be used in the treatment of hemorrhoids. The main roots and trunk of the T. chamaedrys L., one of the most common and most researched species, are boiled by drying and the plant extract obtained is prepared and consumed in a manner similar to that of the T. orientale L. (Gürhan and Ezer 2004; Özdemir and Alpınar, 2015; Koca et al, 2017). It has been reported that the extract of T. polium L. subtilis contains diterpenoids, 5-7glycosides, thymols, carvacrols and volatile essences and has antimicrobial, antipyretic and anti-inflammatory effects (Bahmani et al., 2015; Sezik et al., 2001).

In the ethnopharmacological studies conducted, $T$. orientale L. plant is added as a spice into cookings in Anatolia and used in the field of food by making tea from flowers. (Korkmaz and Alpaslan, 2014). In the literature, we have examined the components of $T$. orientale $L$. plant extracts and antioxidant activities and found that the plant has strong antioxidant properties of luteolin7-O-glucoside and luteolin7-O-rutinoside isolated from acetone extract and has the effect of eliminating radicalic oxygen species (ROS) (Cakir et al., 2006).

The investigations conducted on the research on the subspecies $T$. orientale $L$. and its effects on the medical uses seem to be more limited than the studies on other subspecies. Although there are reports that some subtypes belonging to the Teucrium line have been used for the treatment of hemorrhoids, there has been no study 
showing that $T$. orientale $L$ subtype is used for the treatment of hemorrhoids. In this respect, it is important to study the pharmacological activity of this plant which has been used in the hemorrhoid treatment for about ten years and grown in the rural area of Beyköy Village of Samsun province Havza District. In this study, it is aimed to investigate the effectiveness of $T$. orientale $L$. plant in the treatment of hemorrhoids by a questionnaire survey with real patients using this plant extract.

\section{Materials and Methods}

\section{Collection and Drying of the Plant}

In the scope of the study, plant samples were collected from Samsun/Havza/Beyköy Village. The local people assisted in the collection and preparation of the $T$. orientale $L$. plant. The plant known to be used for hemorrhoid treatment by the not only Beyköy villagers but also local people living in the neighboring villages is gathering after the flowering of the plant during JuneJuly. The first week of July, plant was viewed at the natural site and was collected together with local people. Local people say that it is important that the plant must be collected close to its stems, because there are parts close to the stems of the actual therapeutic feature. After collecting, the plant is dried in the shade without washing and chopping. Collected plants are dried in the cool place where has air current without contact with the sun for 7 to 8 days. In addition, the plant is mixed to prevent from the occasional mildew. After drying, the plant is stored cool and dry until used.

\section{Preparation of The Extract}

The aqueous extract of dried $T$. orientale $L$. plant is prepared to be used in the treatment of hemorrhoids. For this purpose, water that is a polar solvent was used. The preparation of the extract was observed on the site and prepared with the local people. the dried plant is thrown out into the boiling water and cooked for about 30 minutes to prepare the extract. The cooled mixture is filtered to separate the woody parts of the plant to obtain an aqueous extract. After the preparing, it is stored in a refrigerator at $+4{ }^{\circ} \mathrm{C}$ and is recommended to be consumed in 15 to 20 days. It is also said that in the interviews it was made at different concentrations according to the degree of illness.

\section{Usage of The Extract}

Prepared plant extract is used for hemorrhoid treatment for 10-15 days on average. It is recommended that you drink a glass on an empty stomach every morning and do not consume it with any other substance or sweetener. It is also recommended that nothing mustn't be eaten and drunk within half an hour after drinking the extract. It was determined that, because of the poor taste of plant extracts, if patients have had any early benefit, either they previously stopped using plant extracts or used sweetener.

In these patients who thought that it has been observed that the symptoms of the disease have passed, it is seem that the disease has recurred after a while. For this reason, it is very important for patients to use this herb extract regularly and with caution. It is observed that the period of use of plant extracts is increased in patients whose symptoms are not completely overcome even though they use plant extract regularly.

\section{Survey Work}

It has been found that $T$. orientale $L$. plant is used by locals and their relatives in the treatment of hemorrhoids, and then its usage have spared by sharing information by the people who benefited from the extract. A total of 89 patients, of whom 19 were women and 70 men, who had used $T$. orientale $L$. extracts in the past, were joint to participate in our survey study. In general, we asked some questions to the patients about past stories about illnesses, family story, what changes in complaints after using plant extracts and possible side effects for investigation of the effectiveness of $T$. orientale $L$. plant in hemorrhoidal treatment.
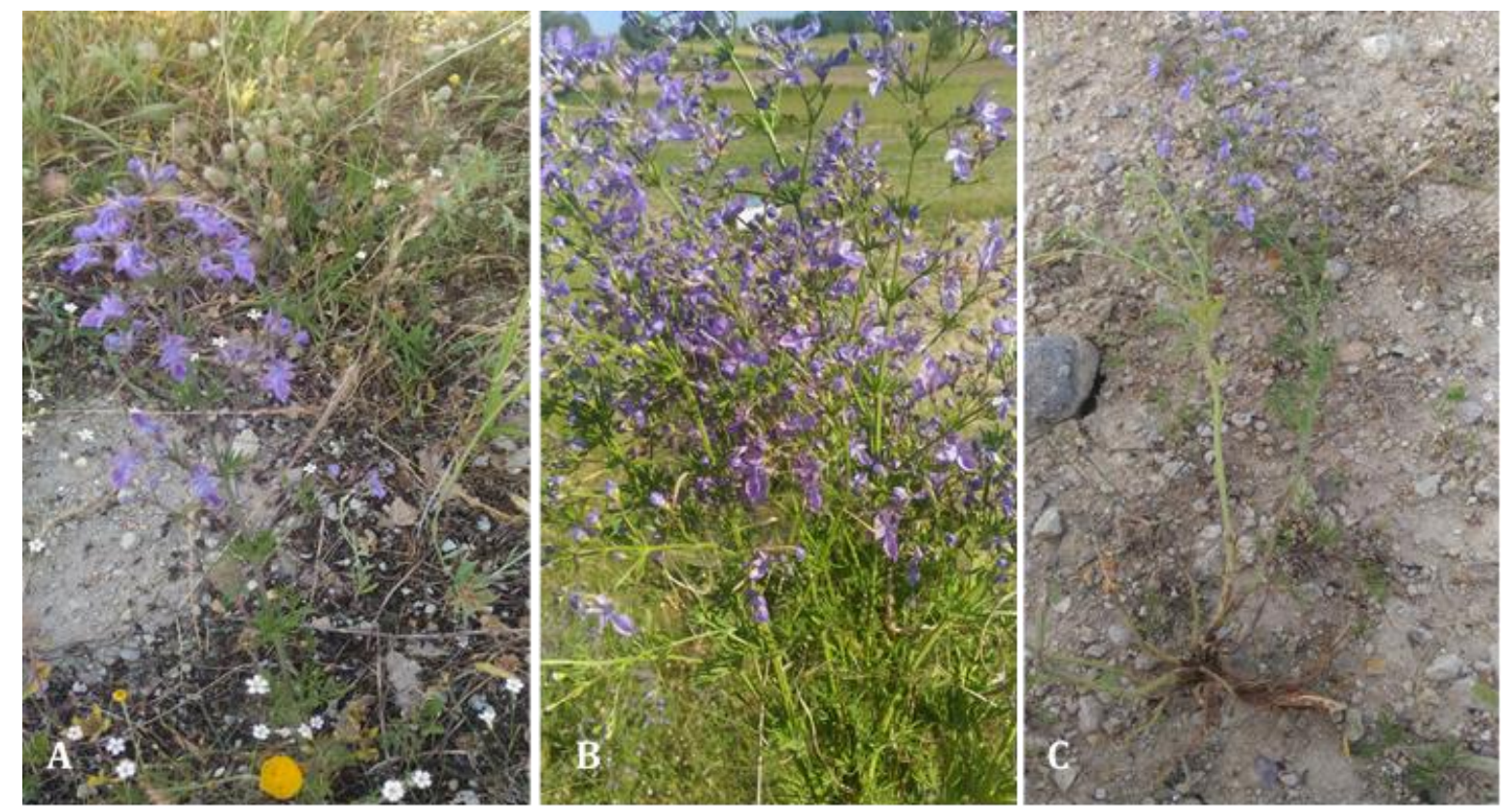

Figure 1: T.orientale L. plant and its ecologic environment 


\section{Results and Discussion}

The answers to the questions about the disease stories and family susceptibilities of the patients are given in Table-1. As seen in Table 1, 41.58\% of the surveyed had previously received medical treatment in their treatment. This less ratio can be explained by the feelings of embarrassment in the patients about their illness like that Ahad et. al. (2010) study. In contrast, uses ratio of hemorrhoid drugs is $66.3 \%$ indicate that patients receive help from the other patients who are suffering from similar illnesses rather than seeking physician. In $59.3 \%$ of the medication users, complaints did not pass during medication use, and in $52.5 \%$ of patients, complaints have resumed with the medication leaved.

Only $27 \%$ of respondents used other plant curatives before, and none of them have fully recovered with the application of these curatives. Approximately half of the respondents reported to have another hemorrhoid patients in their family. In addition, all of the patients using the extract reported no side effects after the use. It is very important statement for reliability of the plant.

The relationship between age distribution and the answers to the question "My disease has passed since I used plant extracts" is shown in the Figure 2. It seems that the therapeutic effect of the plant is decreased by increasing age. As can be seen from the graphic, the highest rate of recovery is seen in the age range of 20-29 years with $70 \%$ and the lowest rate of recovery is seen in patients over 41-60 years of age with $41 \%$. Another result that is clearly seen in the survey results is that few of the patients did not observed any improvement.

Table 1 Questions and answers about the patients' narratives about hemorrhoid disease (The values are given as percentage)

\begin{tabular}{|c|c|c|c|}
\hline Survey Questions & Yes & Partially & No \\
\hline 1. I got help from a physician about this disease before. & 57.30 & 1.12 & 41.58 \\
\hline 2. I used medications for this disease before. & 66.3 & 1.12 & 32.58 \\
\hline 3. My complaints passed when I was using medications. & 17 & 23.7 & 59.3 \\
\hline 4. After quitting the medications, my complaints started again. & 52.5 & 8.5 & 39 \\
\hline 5. There are other individuals in my family who have hemorrhoids. & 53 & - & 47 \\
\hline 6. Have you ever used other herbal remedies for this disease before? & 27 & - & 73 \\
\hline 7. The other herbal remedies I used were healed my illness. & - & 12.5 & 87.5 \\
\hline 8. Did any side effects occur when using plant extracts? & - & - & 100 \\
\hline
\end{tabular}

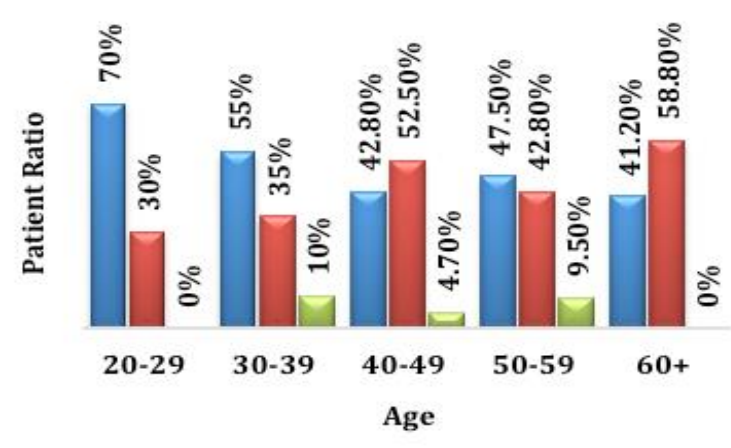

A Healed $\square$ Partially $\square$ Not Healed

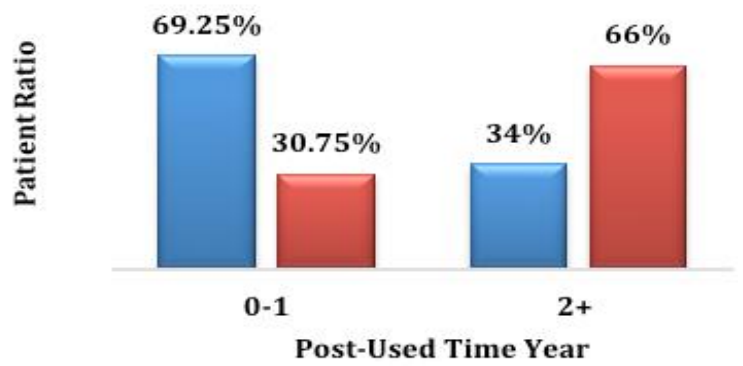

B

घealed $⿴$ Partially

Figure 2 (a) Age-related examination of recovery status of patients using plant extract. (b) Investigation of the effect of herbal treatment according to the time elapsed since the use of the plant extract by interviewers.

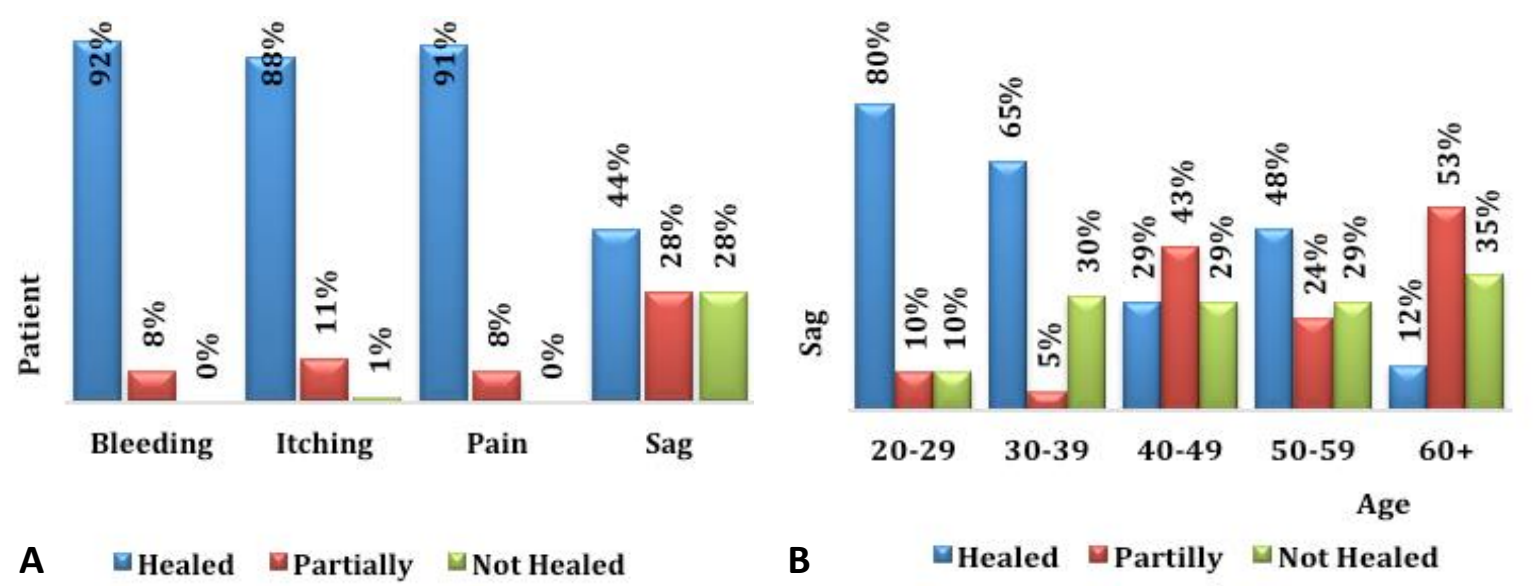

Figure 3 (a) Recovery of illness-related symptoms such as bleeding, itching, pain, and sagging after the using plant extract. (b) The relationship between age-related sagging of the skin in patients using plant extract. 


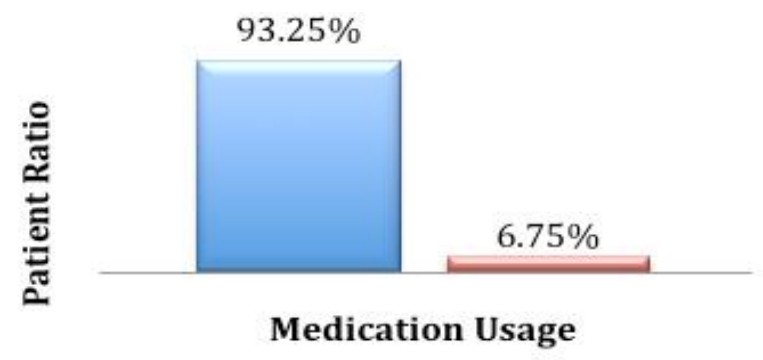

A $\square$ Used Regularly $\square$ Used Non-Regularly

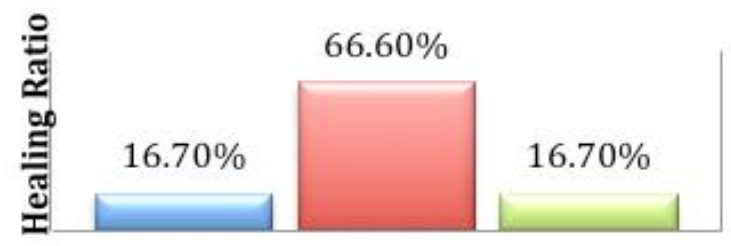

Healing Status

B $\square$ Healed $\square$ Partially $\square$ Not Healed

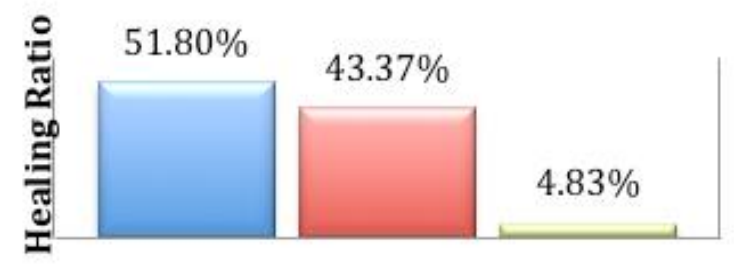

\section{Healing Status}

\section{C $\square$ Healed $\square$ Partially $\square$ Not Healed}

Figure 4 (a) Patient's medication use pattern (b) Patient's healing rate of regularly not using medication. (c) The rate of recovery for regular users of medication.

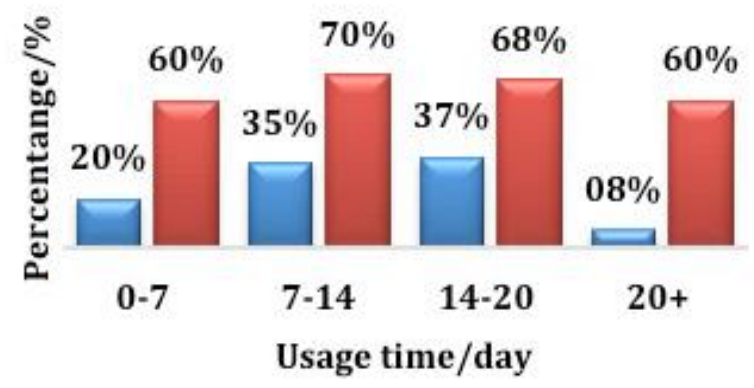

\section{$\square$ Percentage of patient $\square$ Percentage of healing}

Figure 5 Duration of use of herbal extracts by the patients, and evaluation of these periods of use together with the recovery rate.

As can be seen from Figure 2.3.b, the rate of recovery in patients using herbal extracts for 1 year or more seems to increase, whereas the rate of recovery for patients using herbal extracts $2 \leq$ years ago appears to decrease. It is indicated that the herbal remedy remains active and that symptoms decrease and/or complete recovery in patients who have recently used herbal extracts. In contrast, in patients who use $2 \leq$ years ago, it shows that the therapeutic properties of the plant have decreased over time and/or the effectiveness has completely disappeared, depending on such factors as the age of the patient and the stage of the disease.

Questions were asked to patients who used plant extracts to find out what changes were made in complaints about illnesses. The patients using plant extracts reported that their complaints were healed at different ratio; at $92.1 \%$ were bleeding, $87.8 \%$ were itching, 91\% were pain and $43.8 \%$ were sagging (Figure 3.a). In the question of whether the sag in the skin completely disappeared, $43.8 \%$ of the patients using plant extracts gave Yes, $28.1 \%$ Partially and $28.1 \%$ answered No. As shown in figure 3.b, the disappearance of the sagging of the skin due to hemorrhoid disease is the lowest among the symptoms that are lost. It is thought to be due to the tissue regeneration gets slow by the age, and nutrition habits also effect on the healing. In addition, the herbal treatment was not used under the controlled of the physician. So, the patients didn't take any special treatment that was given according to their status by the expert.

The plant extract seems to improve the other indications at a high rate but does not fully cure the degeneration of the skin, especially due to age. So, in figure 3.b, in younger patients using plant extracts seem the sagged tissue in the skin was healed compared to elderly patients. $80 \%$ of patients aged 20-29 years reported that after the use of herbal extracts, the sagged tissue in the skin disappeared completely, while only $12 \%$ of patients over $60+$ years of age reported the sagged tissue in their skin disappeared. The reason for this can be thought to be due to the fact that tissue regeneration is very rapid in young people. It can also be explained in the elderly that if the hemorrhoid cushions are thought to be sagged with the loosening of the supporting connective tissue, depending on the effect of aging, this have caused a lower recovery rate than the younger ones.

Whether or not they use the plant extract in their healing, as suggested, has also been investigated (Figure 4). Only $6.75 \%$ of respondents used the extract differently than recommended (Figure 4.a).

It is seen that the rate of healing is lower in irregular users. Those who regularly use the extract, on the other hand, show a recovery rate of $51.8 \%$ (Figure 4.a-4.b).

This shows that the local people who prepare and use the extract have a positive impact on the accuracy of the experiences they have achieved over the years and the recommended use for the treatment.

It was seen that the duration of extractive use had an effect on recovery. In general, the rate of healing was similarly found to be $68-70 \%$ in those who used during the 14 days and more (Figure 5).

In the study it was seen that in $64 \%$ of the plant extracts users, complaints were cured a few weeks later over using the extract. However, the percentage of people who have immediately healed after using the extract remains at $9 \%$ (Figure 6). Therefore, it can be said that the period of healing after the completion of plant extract treatment is not dependent on age firstly. 

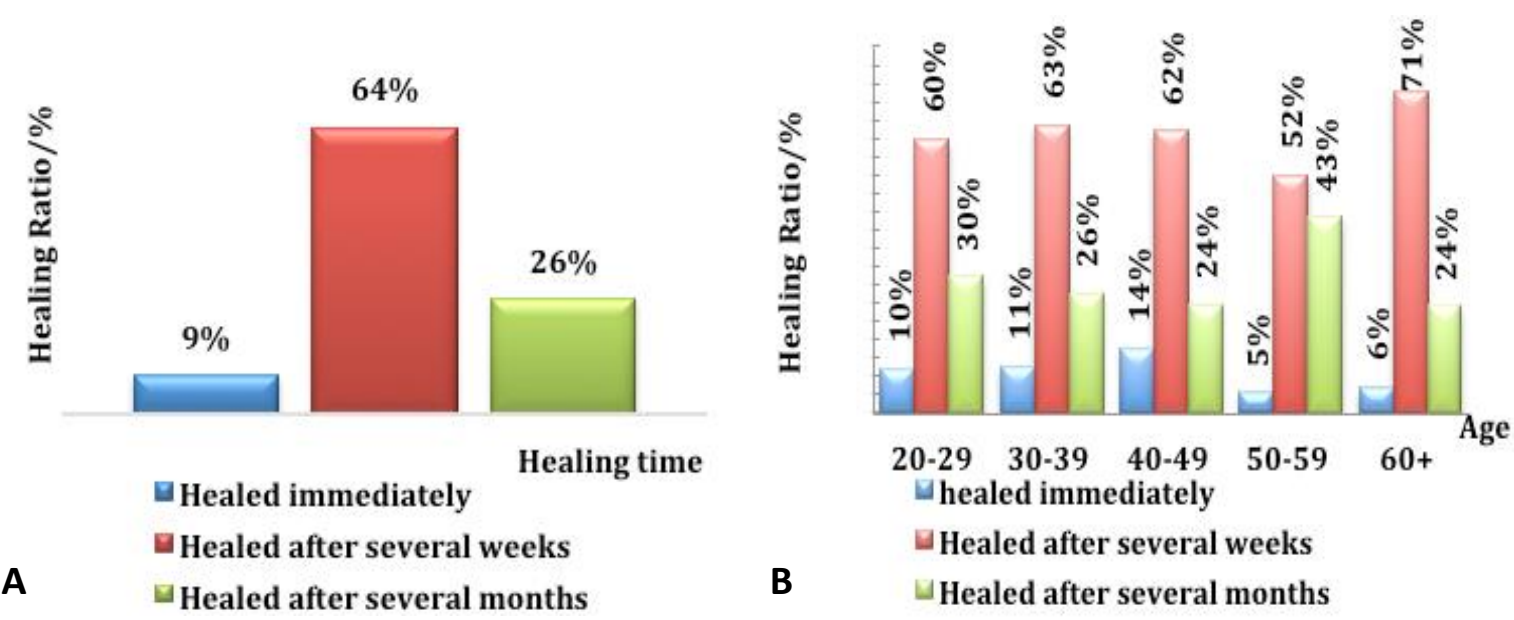

Figure 6 After the patients used plant extracts, examination of how long the healing has been observed.

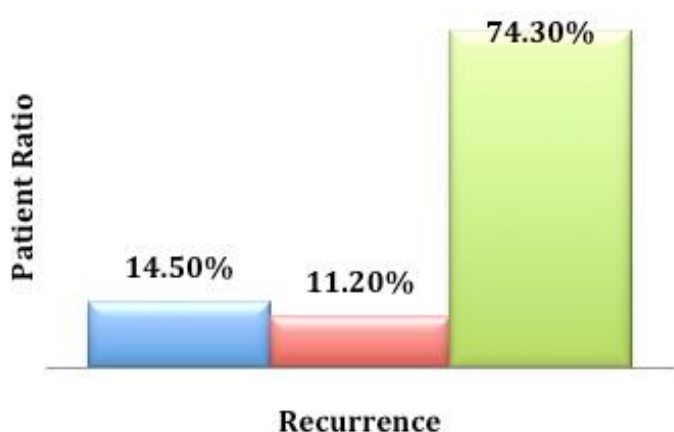

A

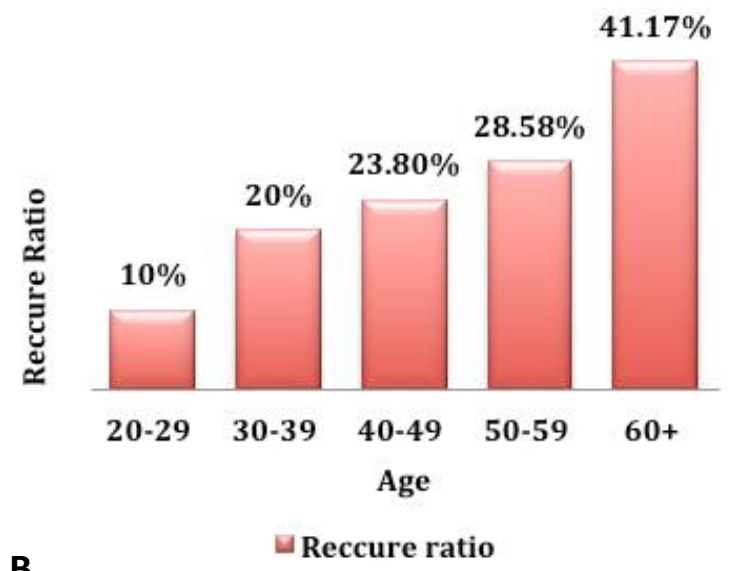

B

$\square$ Reccure ratio

Figure 7 In Patients recurred of their disease after using plant extracts.

Recurred or not to the same complaints about their illnesses over done the cure were asked to the participants of the survey. According to the answers received, $74.3 \%$ of the patients reported that their illnesses did not recur, $11.2 \%$ had partial recurrent and $14.5 \%$ had recurred (Figure 7).

\section{Conclusion}

It has been determined that $T$. orientale $L$. was used in the treatment of hemorrhoid among the people in our researches carried out in Beyköy village in Havza district of Samsun province. Despite reports that some subtypes belonging to the Teucrium type have been used for the treatment of hemorrhoids, could not reached any studies showing that the $T$. orientale $L$. subtype has been used in the treatment of hemorrhoids. In alternative medicine applications used in hemorrhoid treatment, plant mixtures are generally used. However, it has been seen that these mixtures used for therapeutic purposes have limited activity and are inadequate to completely heal hemorrhoids. For this reason, because of the extract obtained from $T$. orientale $L$. plant is used in hemorrhoid treatment alone and has a high success rate, it is distinguished it from other herbal cures. In the survey, it was determined that everyone who used this plant extract benefited in varying proportions. As a result, patients has recommended this extract to other patients, and in this way, their use is spread the around.

In reviewing the questionnaires, it was determined that the rate of improvement and duration of the healing were primarily age-related. However, it is also very important that plant extract must be used as recommended. Namely, it has been determined that the interviewers whose disease was recurred generally used the extract differently than the recommendation.

Sagged tissue in the skin that is one of the hemorrhoidal complaints in the advanced stage is more easily healed in younger individual. This can be explained by the fact that tissue regeneration is faster at younger ages. It is also confirmed by survey results that due to the tissue regeneration ability of the elderly individuals is slowing down over time, tissue sags not fully recover.

The therapeutic effect of $T$. Orientale $L$. extract in the body has been shown to change with the time passed after its used. For this reason, even if this cure is beneficial, patients need to reuse this extract in later periods. The duration of this reuse varies depending on factors such as age, sex and the stage of the illness.

After the use of the extracts, the percentage of recurrence with all complaints of the disease remained below $25 \%$. This rate is a significant success in the use of $T$. orientale $L$. exract alone in the treatment of hemorrhoids. However, the fact that none of the surveyed 
patients complain of adverse side effects also increases the reliability of extract.

\section{Acknowledges}

We would like to thank Mr. Mahmut Demirci and Mr. Ahmet Demirci for their assistance in collecting the plant and preparing the extract. We also thank Zeki Aytaç, a faculty member of the Biology Department of the Gazi University Faculty of Science and Literature, for his help during plant identification.

\section{References}

Acheson AG, Scholefield JH. 2008. Management of haemorrhoids. British Medical Journal. 336: 380-383. DOI:10.1136/bmj.39465.674745.80. PMCID: PMC2244760.

Ahad HA, Kumar CS, Reddy KK, Kranthi G, Manesh K, Teja K, Kumar M. 2010. Herbal Treatment of Hemorrhoids. JITPS. 1(5): 236-242. ISSN: 0975-8593. Available from: www.itpsonline.net (20.01.2016).

Alabaz Ö. 2007. Etiyoloji ve Fizyopatoloji. In: (Baykan A., Füzün M., Zorluoğlu A.). Hemoroit Hastalığı ve Tedavisi. İstanbul: Avrupa Tıp Kitapçılık. 1: 27-29. ISBN: 9978-9756257-27-2.

Altundağ E, Öztürk M. 2011. Ethnomedicinal Studies on the Plant Resources of East Anatolia, Turkey. Procedia Social and Behavioral Sciences. 19: 754-756. DOI: 10.1016/j.sbspro.2011.05.195.

Bağcı E, Yazgın A, Hayta Ş, Çakılcıŏlu U. 2010. Composition of the Essential Oil of Teucrium Chamaedrys L. (Lamiaceae) from Turkey. Journal of Medicinal Plants Research. 4(23): 2587-2588. DOI: 10.5897/ JMPR10.823. ISSN: 1996-0875.

Bahmani M, Saki K, Shahsavari S, Rafieian-Kopaei M, Sepahvand R, Adineh A. 2015. Identification of medicinal plants effective in infectious diseases in Urmia, northwest of Iran. Asian Pacific Journal of Tropical Biomedicine. 5(10): 858-864. DOI: 10.1016/j.apjtb.2015.06.004.

Brozovich M, Read TE. 2007. What Are Hemorrhoids? Anatomy, Classification, Symptoms and Diagnosis. Seminars in Colon and Rectal Surgery. 18: 147-150. DOI: 10.1053/j.scrs.2007.07.003.

Chugh A, Singh R, Agarwal PN. 2014. Management of hemorrhoids. İndian Journal of Clinical Practice. 25(6): 577 580.

Cirocco WC. 2007. Why Are Hemorrhoids Symptomatic? The Pathophysiology and Etiology of Hemorrhoids. Seminars in Colon and Rektal Surgery. 18: 152-159. DOI: 10.1053/j.scrs.2007.07.004.

Çakır A, Mavi A, Kazaz C, Yıldırım A, Küfrevioğlu Oİ. 2006. Antioxidant Activities of the Extracts and Components of Teucrium orientale L. var orientale. Turkish Journal of Chemistry. 30: 483-494.

Çalışkan UK, Aka C, Öz MG. 2017. Plants Used in Anatolian Traditional Medicine for the Treatment of Hemorrhoid. Records of Natural Products. 11(3): 238-247. ISSN: 130761-67.

Ganz RA. 2013. The Evaluation and Treatment of Hemorrhoids: A Guide for the Gastroenterologist. Cilinical Gastroenterology and Hepatology. 11(6): 597-601. DOI: 10.1016/j.cgh.2012.12.020. PMID: 23333220.
Gearhart SL. 2004. Symptomatic Hemorrhoids. Advances in Surgery. 38: 603-605. DOI: 10.1016/j.disamonth. 2004.11.004.

Güneş S, Savran A, Paksoy MY, Koşar M, Çakılcıŏlu U. 2017. Ethnopharmacological Survey of Medicinal Plants in Karaisalı and Its Surrounding (Adana-Turkey). Jounal of Herbal Medicine. 8: 68-74. DOI: 10.1016/j.hermed. 2017.04.002.

Gürhan G, Ezer N. 2004. Halk Arasında Hemoroit Tedavisinde Kullanılan Bitkiler-I. Hacettepe Üniversitesi Eczacılık Fakültesi Dergisi. 24(1): 41-45.

Kaidar-Person O, Person B, Wexner SD. 2007. Hemorrhoidal Disease: A comprehensive Review. American College of Surgeons. 204(1): 102-113. DOI: 10.1016/j.jamcollsurg. 2006.08.022. ISSN: 1072-7515.

Kann BR, Whitlow CB. 2004. Hemorrhoids: Diagnosis and management. Techniques in Gastrointestinal Endoscopy. 6(1): 6-10. DOI: 10.1053/j.tgie.2004.01.004.

Korkmaz M, Alpaslan Z. 2014. Ergan Dağı (Erzincan-Türkiye)' nın Etnobotanik Özellikleri. Bağbahçe Bilim Dergisi. 1(3): 14. Available from: http://edergi.ngbb.org.tr/ (03.02.2015). E-ISSN:2148-4015.

Lattimer JM, Haub MD. 2010. Effects of Dietary Fiber and Its Components on Metabolic Health. Nutrients. 2: 1266-1289. DOI: $10.3390 /$ nu2121266. PMID: 22254008

Moult HP, Aubert M, Parades VD. 2015. Classical Treatment of Hemorrhoids. Journal of Visceral Surgery. 152: S3-S9. Available from: www.sciencedirect.com (11.10.2014). DOI: 10.1016/j.viscsurg.2014.09.012.

Osmanoğlu H, Ünalp ÖV. 2007. Tanı ve Ayırıcı Tanı. In: (Baykan A., Füzün M., Zorluoğlu A.). Hemoroit Hastalığ1 ve Tedavisi. İstanbul: Avrupa Tıp Kitapç1lık. 1: 37-38. ISBN: 9978-975-6257-27-2.

Özdemir E, Alpınar K. 2015. An Etnobotanical Survey of Medicinal Plants in Western Part of Central Taurus Mountains: Aladaglar (Nigde-Turkey). Journal of Ethnopharmacology. 166: 53-61. DOI: 10.1016/j.jep.2015.02.052. PMID: 25771355

Popowich DA, Orkin BA. 2013. Approaching the Consult for "Hemorrhoids". Seminars in Colon and Rectal Surgery. 24: 72-73. DOI: 10.1053/j.scrs.2013.02.003.

Sack J. 2003. Pathophysiology of Hemorrhoidal Disease. Seminars in Colon and Rectal Surgery. 2(14): 93-94. DOI: 10.1053/scrs.2003.00003-4.

Sevgi E, Kızılarslan Ç. 2013. Bir İsim Çok Bitki- Mayasıl Otu. Avrasya Terim Dergisi. 1(1): 20-26. ISSN: 2147-7507.

Sezik E, Yeşilada E, Honda G, Takaishi Y, Takeda Y, Tanaka T. 2001. Traditional medicine in Turkey X. Folk medicine in Central Anatolia. Journal of Ethnopharmacology. 75: 95115. PMID: 11297840

Şen D. 2007. Sinıflandırma ve Semptomatoloji. In: (Baykan A., Füzün M., Zorluoğlu A.). Hemoroit Hastalığı ve Tedavisi. İstanbul: Avrupa Tip Kitapç1lık. 1: 34-35. ISBN: 9978-9756257-27-2.

Tetik F, Civelek Ş, Çakılcığlu U. 2013. Traditional Uses of Some Medicinal Plants in Malatya (Turkey). Journal of Ethnopharmacology. 146: 335-339. DOI: 10.1016/j.jep.2012.12.054. PMID: 23333750

Warusavitarne J, Phillips RKS. 2007. Hemorrhoids Throughout History- A Historical Perspective. Seminars in Colon and Rectal Surgery. 140-145. DOI: 10.1053/j.scrs.2007.07.002.

URL-1: http://www.tubives.com/index.php?sayfa=1\&tax_id=7433 